\title{
PENINGKATAN KESEHATAN LANSIA MELALUI POSYANDU LANSIA DENGAN PENGAKTIFAN KEGIATAN SENAM LANSIA DI DESA PAGERNGUMBUK KECAMATAN WONOAYU KABUPATEN SIDOARJO
}

\author{
Zulfa Rufaida $^{\text {1), Sri Wardini Puji Lestari }}{ }^{2)}$, Abdul Muhith ${ }^{3)}$ \\ ${ }^{1}$ Prodi Kebidanan, STIKes Majapahit Mojokerto \\ email: zulfarufaida@gmail.com \\ ${ }^{2}$ Prodi Kebidanan, STIKes Majapahit Mojokerto \\ email: sriwardinipujilestari@gmail.com \\ ${ }^{3}$ Prodi Keperawatan, STIKes Majapahit Mojokerto \\ email: abdulmuhith1979@gmail.com
}

\begin{abstract}
Jumlah lansia semakin meningkat, oleh karena itu pemerintah telah merumuskan berbagai kebijakan pelayanan kesehatan usia lanjut ditujukan untuk meningkatkan derajat kesehatan dan mutu kehidupan lansia untuk mencapai masa tua bahagia dan berdaya guna dalam kehidupan keluarga dan masyarakat sesuai dengan keberadaannya. Tujuan dari pengabdian masyarakat ini adalah meningkatkan pengetahuan tentang Posyandu Lansia dan keaktifan mengikuti senam lansia.

Metode yang digunakan adalah ceramah, diskusi, role play dan pendampingan, Sasaran adalah lansia di Desa Pagerngumbuk Kecamatan Wonoayu Kabupaten Sidoarjo, pelaksanaan kegiatan bulan April - Juni 2018. Analisa data menggunakan distribusi frekuensi.

Hasil yang diperoleh, peserta penyuluhan sebanyak 34 orang dengan hasil nilai means pre test 46.18 dan post test 87.94. Hasilnya signifikan terjadi peningkatan pengetahuan 0.000 dengan nilai $\mathrm{t}=-16.85$, Dan $95 \% \mathrm{CI}$ antara $-46.81--36.72$, artinya pengaruhnya kuat karena tidak melewati angka 1; pemberian perlakuan bisa meningkatkan $3-4 x$ pengetahuan dibanding dengan tidak diberikan. Sedangkan untuk pendampingan senam lansia jumlah peserta rata - rata 27 orang.

Peserta penyuluhan Posyandu Lansia antusias terhadap materi yang disampaikan. Terjadi peningkatan pengetahuan Lansia tentang peran Posyandu lansia dan pentingnya senam lansia. Petugas kesehatan selalu memberikan informasi tentang kegiatan Posyandu Lansia kepada kader, perangkat desa dan masyarakat secara berkesinambungan.
\end{abstract}

\section{Kata Kunci: Posyandu Lansia, Senam, Lansia}

\section{Abstract}

The number of elderly people is increasing, therefore the government has formulated various health care policies aimed at improving the health status and quality of life of the elderly to achieve a happy and efficient old age in family and community life according to their existence. The purpose of this community service is to increase knowledge about the Elderly Posyandu and to be active in participating in elderly gymnastics.

The methods used are lectures, discussions, role play and mentoring. The targets are the elderly in Pagerngumbuk Village, Wonoayu District, Sidoarjo Regency, the implementation of activities from April to June 2018. Data analysis uses frequency distribution.

The results obtained, there were 34 participants with the mean pre-test and post-test scores of 87.94. The result is a significant increase in knowledge of 0.000 with a value of $t=-16.85$, and a 95\% CI between $-46.81--36.72$, meaning that the effect is strong because it does not pass 1; giving treatment can increase 3-4x knowledge compared to not given. Meanwhile, for elderly exercise assistance, the number of participants averaged 27 people.

The Posyandu Elderly counseling participants were enthusiastic about the material presented. There is an increase in the knowledge of the elderly about the role of the elderly Posyandu and the importance of elderly exercise. Health workers always provide information about 
the activities of the Elderly Posyandu to cadres, village officials and the community on an ongoing basis.

Keywords: Elderly Posyandu, Gymnastics, Elderly

\section{A. PENDAHULUAN}

Pelayanan kesehatan di tingkat masyarakat adalah Posyandu lansia, pelayanan kesehatan lansia tingkat dasar adalah Puskesmas, dan pelayanan kesehatan tingkat lanjutan adalah Rumah Sakit. Pelayanan Posyandu lansia adalah pos pelayanan terpadu untuk masyarakat usia lanjut di suatu wilayah tertentu yang sudah disepakati, yang digerakkan oleh masyarakat dimana mereka bisa mendapatkan pelayanan kesehatan Posyandu lansia merupakan pengembangan dari kebijakan pemerintah melalui pelayanan kesehatan bagi lansia yang penyelenggaraannya melalui program Puskesmas dengan melibatkan peran serta para lansia, keluarga, tokoh masyarakat dan organisasi sosial dalam penyelenggaraannya (Erfandi, 2008).

Salah satu indikator keberhasilan pembangunan adalah semakin meningkatnya usia harapan hidup penduduk. Populasi lansia pada masa ini semakin meningkat, oleh karena itu pemerintah telah merumuskan berbagai kebijakan pelayanan kesehatan usia lanjut ditujukan untuk meningkatkan derajat kesehatan dan mutu kehidupan lansia untuk mencapai masa tua bahagia dan berdaya guna dalam kehidupan keluarga dan masyarakat sesuai dengan keberadaannya. Sebagai wujud nyata pelayanan sosial dan kesehatan pada kelompok usia lanjut ini, pemerintah telah mencanangkan pelayanan pada lansia melalui beberapa jenjang (Erfandi, 2008).

Jumlah penduduk lanjut usia menunjukkan peningkatan dari tahun ke tahun. Hal yang sejalan dengan meningkatnya usia harapan hidup serta menjadi tanda membaiknya tingkat kesejahteraan masyarakat. Dari hasil Sensus Penduduk tahun 2010 menunjukkan bahwa Indonesia termasuk lima besar negara dengan jumlah penduduk lanjut usia terbanyak di dunia yaitu mencapai 18,1 juta jiwa pada 2010 atau 9,6 persen dari jumlah penduduk (Abdi, 2013). Sedangkan di wilayah Jawa timur tahun 2010 lansia sebanyak 7.956.188 jiwa dan 3.399.189 jiwa diantaranya $(42,72 \%)$ telah mendapat pelayanan kesehatan (Profil Kesehatan Profinsi Jawa Timur, 2010). Oleh karena itu, Kementerian Kesehatan akan menambah jumlah Puskesmas yang santun bagi lanjut usia karena bertambahnya jumlah penduduk lansia akibat meningkatnya umur harapan hidup menyebabkan pelayanan kesehatan yang ramah bagi kelompok tersebut semakin dibutuhkan. Dari Data Kementerian Kesehatan, saat ini ada 528 Puskesmas Santun Lansia di 231 Kabupaten/Kota di Indonesia. Jumlah kelompok lanjut Usia (Posyandu 
Lansia) yang memberikan pelayanan promotif dan preventif ada 69.500 yang tersebar di semua provinsi di Indonesia. Namun, implementasi posyandu lansia saat ini belum berjalan maksiamal (Kompas, 2013).

GERMAS merupakan gerakan nasional yang diprakarsai oleh Presiden RI yang mengedepankan upaya promotif dan preventif, tanpa mengesampingkan upaya kuratifrehabilitatif dengan melibatkan seluruh komponen bangsa dalam memasyarakatkan paradigma sehat. Untuk menyukseskan GERMAS, tidak bisa hanya mengandalkan peran sektor kesehatan saja. Peran Kementerian dan Lembaga di sektor lainnya juga turut menentukan, dan ditunjang peran serta seluruh lapisan masyarakat. Mulai dari individu, keluarga, dan masyarakat dalam mempraktekkan pola hidup sehat, akademisi, dunia usaha, organisasi kemasyarakatan, dan organisasi profesi dalam menggerakkan anggotanya untuk berperilaku sehat; serta Pemerintah baik di tingkat pusat maupun daerah dalam menyiapkan sarana dan prasarana pendukung, memantau dan mengevaluasi pelaksanaannya. (Kemenkes, 2017).

Desa Pagerngumbuk Kecamatan Wonoayu Kabupaten Sidoarjo memiliki jumlah penduduk sekitar 520.000 jiwa yang terbagi menjadi 3 dusun, yaitu dusun Pager, Ngumbuk dan Bendet. Mata pencaharian penduduk setempat bervariasi, paling banyak adalah buruh petani, dengan demikian sebagian besar penghasilan penduduk kurang dari UMR. Jumlah rumah secara keseluruhan adalah 625 rumah. Analisis status kesehatan satu tahun terakhir didapatkan frekuensi penyakit yang sering diderita masyarakat adalah ISPA, yaitu 22 kunjungan. Kunjungan lansia sakit sebanyak 46 kunjungan. Tapi pada bulan-bulan terakhir pemanfaatan posyandu lansia menurun/ tidak teratur dikarenakan jadwal yang tidak menetap dari Kader sehingga motivasi lansia untuk pergi ke posyandu lansia menurun. Mereka (lansia) pergi keposyandu lansia hanya pada saat mereka merasa sakit saja, ketika mereka merasa sehat jarang pergi/ memanfaatkan posyandu lansia.

Peningkatan penduduk usia lanjut dapat meningkatkan penyakit degeneratif di

Masyarakat. Tanpa diimbangi dengan upaya promotif dan preventif maka beban sosial yang ditimbulkan maupun biaya yang akan diikeluarkan untuk pelayanan kesehatan usia lanjut akan cukup besar, salah satu sarana pelayanan bagi usia lanjut dilaksanakan melalui posyandu lansia (Profil kesehatan Magetan, 2012). Posyandu lansia berkaitan dengan peningkatan sarana untuk mempertahankan kesehatan lansia, mencegah gangguan kesehatan, mengobati penyakit dan upaya rehabilitasi bagi lansia dengan program- 
program antara lain pengukuran tinggi badan dan berat badan, pemeriksaan tekanan darah, pemeriksaan berkala dan pengobatan ringan, latihan fisik seperti olahraga dan diberikan penyuluhan-penyuluhan tentang kesehatan. Sehingga lansia yang teratur dalam memanfaatkan posyandu lansia akan terkontrol kesehatannya. Peran keluarga dalam merawat lanjut usia sangat penting untuk menjaga kesehatan dan kesejahteraan usia lanjut. Begitu juga dengan lansia, dengan adanya peran keluarga yang baik dan mendukung akan memberikan motivasi dalam diri lansia untuk menjaga kesehatannya dan teratur datang ke posyandu lansia. Dengan demikian derajat kesehatan lansia akan meningkat sehingga tercapai masa tua yang bahagia dan sejahtera. (Azizah, 2011)

Posyandu lansia merupakan suatu fasilitas pelayanan kesehatan yang berada di desa yang bertujuan untuk meningkatkan kesehatan masyarakat khususnya bagi warga yang sudah berusia lanjut. Posyandu lansia adalah wahana pelayanan bagi kaum usia lanjut yg dilakukan dari, oleh, dan untuk kaum usia yg menitikberatkan pada pelayanan promotif dan preventif tanpa mengabaikan upaya kuratif dan rehabilitative. Posyandu lansia merupakan upaya kesehatan lansia yang mencakup kegiatan pelayanan kesehatan yang bertujuan untuk mewujudkan masa tua yang bahagia dan berdayaguna.
Oleh karena itu, penting sekali lansia tahu bagaimana meningkatkan kualitas hidup dengan aktif ke Posyandu Lansia.

\section{B. KAJIAN LITERATUR}

\section{a. Pengertian}

Posyandu lansia adalah pos pelayanan terpadu untuk masyarakat usia lanjut di suatu wilayah tertentu yang sudah disepakati, yang digerakkan oleh masyarakat dimana mereka bisa mendapatkan pelayanan kesehatan. Posyandu lansia merupakan pengembangan dari kebijakan pemerintah melalui pelayanan kesehatan bagi lansia yang penyelenggaraannya melalui program Puskesmas dengan melibatkan peran serta para lansia, keluarga, tokoh masyarakat dan organisasi sosial dalam penyelenggaraannya.

\section{b. Tujuan Posyandu Lansia}

\section{1) Tujuan Umum}

Meningkatkan derajat kesehatan lansia untuk mencapai masa tua yang bahagia \& berdaya guna dalam kehidupan keluarga dan masyarakat (Matra, 1996).

\section{2) Tujuan Khusus}

a) Meningkatkan kesadaran lansia untuk membina sendiri kesehatannya

b) Meningkatkan kemampuan \& peran serta masyarakat dalam menghayati \& mengatasi masalah kesh lansia secara optimal 
c) Meningkatkan jangkauan layanan kesehatan lansia. Meningkatkan jangkauan pelayanan kesehatan lansia di masyarakat, sehingga terbentuk pelayanan kesehatan yang sesuai dengan kebutuhan lansia

d) Meningkatnya jenis dan mutu layanan kesehatan lansia. Mendekatkan pelayanan dan meningkatkan peran serta masyarakat dan swasta dalam pelayanan kesehatan disamping meningkatkan komunikasi antara masyarakat usia lanjut.

\section{c. Pelaksanaan Sistem Lima Posyandu Lansia}

Pelaksanaan kegiatan dengan menggunakan sistem 5 meja yaitu:

1. Meja 1: Pendaftaran

Mendaftarkan lansia, kemudian kader mencatat lansia tersebut. Lansia yang sudah terdaftar di buku register langsung menuju meja selanjutnya.

2. Meja 2: Kader melakukan pengukuran tinggi badan, berat badan, dan tekanan darah

3. Meja 3: Pencatatan (Pengisian Kartu Menuju Sehat)

Kader melakukan pencatatan di KMS lansia meliputi : Indeks Massa Tubuh, tekanan darah, berat badan, tinggi badan.

4. Meja 4: Penyuluhan
Penyuluhan kesehatan perorangan berdasarkan KMS dan pemberian makanan tambahan.

5. Meja 5: Pelayanan Medis

Pelayanan oleh tenaga professional yaitu petugas dari Puskesmas/kesehatan meliputi kegiatan : pemeriksaan dan pengobatan ringan.

\section{d. Latihan Gerak Dan Senam Lansia}

Senam adalah serangkaian gerak nada yang teratur dan terarah serta terencana yang dilakukan secara tersendiri atau berkelompok dengan maksud meningkatkan kemampuan fungsional raga untuk mencapai tujuan tersebut (Santosa, 1994). Lansia seseorang individu laki-laki maupun perempuan yang berumur antara 60-69 tahun. (Nugroho 1999:20).

\section{e. Manfaat Olahraga Bagi Lansia}

Manfaat dari olahraga bagi lanjut usia menurut Nugroho $(1999 ; 157)$ antara lain :

1) Memperlancar proses degenerasi karena perubahan usia.

2) Mempermudah untuk menyesuaikan kesehatan jasmani dalam kehidupan (adaptasi)

3) Fungsi melindungi, yaitu memperbaiki tenaga cadangan dalam fungsinya terhadap bertambahnya tuntutan, misalya sakit. Sebagai Rehabilitas Pada lanjut usia terjadi penurunan masa otot serta kekuatannya, laju denyut jantung 
maksimal, tolerasnsi latihan, kapasitas aerobik dan terjadinya peningkatan lemak tubuh. Dengan melakukan olahraga seperti senam lansia dapat mencegah atau melambatkan kehilangan fungsional tersebut. Bahkan dari berbagai penelitian menunjukan bahwa latihan/olah raga seperti senam lansia dapatmengeliminasi berbagai resiko penyakit seperti hipertensi, diabetes melitus, penyakit arteri koroner dan kecelakaan. (Darmojo 1999;81)

\section{METODE PENELITIAN}

Metode yang digunakan dengan memberikan pendidikan melalui penyuluhan untuk meningkatkan pengetahuandan ketrampilan mengenai Peningkatan Kualitas Hidup Lansia dengan Germas di Desa Pagerngumbuk Kecamatan Wonoayu Kabupaten Sidiarjo. Kegiatan yang disampaikan kepada lansia dengan beberapa metode sebagai berikut:

1. Ceramah

Metode ini dipilih untuk menyampaikan teori dan konsep yang sangat prinsip dan penting untuk dimengerti serta dikuasai oleh peserta. Materi yang disampaikan meliputi pengertian, kegiatan apa saja pada Germas untuk lansia.

2. Diskusi
Pada metode ini peserta tanya jawab tentang materi lansia dan Germas pada lansia.

\section{Role Play}

Peserta secara acak diminta untuk menyebutkan kegiatan - kegiatan Germas yang dapat dilakuka oleh Lansia. Untuk metode ceramah, diskusi dan role play dilaksanaka dalam satu waktu.

4. Pendampingan

Metode ini dipilih pada saat tim pelaksana terjun langsung untuk mendampingi lansia dalam melakukan aktivitas fiisk (olah raga) dan konseling gizi dan pengaturan diit lansia dengan Germas. Harapannya setelah kegiatan ini selesai lansia dapat melakukan sendiri dengan mandiri tanpa pendampingan tim pelaksana.

\section{HASIL DAN PEMBAHASAN \\ HASIL PELAKSANAAN}

\section{CERAMAH, DISKUSI, ROLE PLAY}

Pelaksanaan penyuluhan tentang Posyandu Lansia dan Senam Lansia diawali dengan kontrak waktu dengan peserta yaitu saat kegiatan keagamaan tahlilan dengan waktu penyajian 90 menit dan jumlah peserta yang hadir disesuaikan dengan kriteria yaitu lansia laki - laki dan perempuan sebanyak 34 orang. Kegiatan diawali dengan pre test, kemudian kegiatan inti yaitu penyuluhan dengan 
metode ceramah, diskusi, dan role play, kemudian dilanjutkan dengan post test. Kegiatan ini dilaksanakan pada tanggal 04 April 2018 di rumah warga.

\section{PENDAMPINGAN}

Pendampingan dilakukan selama tiga kali, dan disetiap kegiatan pendampingan dibantu oleh mahasiswa dengan jadwal sebagai berikut:

1. Pendampingan 1 dilaksanakan tanggal 06 April 2018

2. Pendampingan 2 dilaksanakan tanggal 04 Mei 2018

3. Pendampingan 1 dilaksanakan tanggal 01 Juni 2018

\section{PELAPORAN}

Berdasarkan hasil evaluasi dapat disimpulkan bahwa peserta penyuluhan Posyandu Lansia dan Senam Lansia antusias terhadap materi yang disampaikan, peserta aktif dalam kegiatan diskusi dengan dibuktikan adanya umpan balik pertayaan, serta saat kegiatan role play peserta aktif menngikuti gerakan yang diajarkan penyaji. Kegiatan tersebut sangat bermanfaat untuk menambah pengetahuan lansia tentang peran Posyandu lansia dan pentingnya senam lansia

Tabel 1.Distribusi Frekuensi Nilai Pre Test Dan Post - Test Pelaksanaan Penyuluhan Posyandu Lansia Dan Senam Lansia

\begin{tabular}{|c|c|c|c|}
\hline No. & Pre - Test & Post - Test & Range \\
\hline
\end{tabular}

\begin{tabular}{|c|c|c|c|}
\hline Resp & & & \\
\hline 1. & 50 & 80 & 30 \\
\hline 2. & 50 & 70 & 20 \\
\hline 3. & 50 & 80 & 30 \\
\hline 4. & 60 & 90 & 30 \\
\hline 5. & 40 & 80 & 40 \\
\hline 6. & 60 & 90 & 30 \\
\hline 7. & 30 & 90 & 60 \\
\hline 8. & 40 & 90 & 50 \\
\hline 9. & 40 & 100 & 60 \\
\hline 10. & 40 & 80 & 40 \\
\hline 11. & 40 & 80 & 40 \\
\hline 12. & 50 & 80 & 30 \\
\hline 13. & 60 & 90 & 30 \\
\hline 14. & 70 & 100 & 30 \\
\hline 15. & 60 & 80 & 20 \\
\hline 16. & 60 & 90 & 30 \\
\hline 17. & 40 & 90 & 50 \\
\hline 18. & 50 & 90 & 40 \\
\hline 19. & 50 & 80 & 30 \\
\hline 20. & 50 & 80 & 30 \\
\hline 21. & 50 & 80 & 30 \\
\hline 22. & 50 & 80 & 30 \\
\hline 23. & 50 & 80 & 30 \\
\hline 24. & 30 & 100 & 70 \\
\hline 25. & 30 & 100 & 70 \\
\hline 26. & 30 & 90 & 60 \\
\hline 27. & 40 & 90 & 50 \\
\hline 28. & 30 & 80 & 50 \\
\hline 29. & 30 & 90 & 60 \\
\hline 30. & 40 & 100 & 60 \\
\hline 31. & 40 & 100 & 60 \\
\hline 32. & 50 & 100 & 50 \\
\hline 33. & 60 & 90 & 30 \\
\hline 34. & 50 & 100 & 50 \\
\hline Means & 46.18 & 87.94 & -41.77 \\
\hline
\end{tabular}

Dari Tabel 1 menunjukkan nilai Pre Test dan Post Test peserta penyuluhan mengalami peningkatan nilai, yang artinya terjadi perubahan pengetahuan tentang Posyandu Lansia dan Senam Lansia.

\section{Hasil Uji T}

Hasilnya signifikan terjadi peningkatan pengetahuan 0.000 dengan nilai $\mathrm{t}=-16.85$. Sementara 95\% CI antara $-46.81--36.72$, artinya pengaruhnya kuat karena tidak melewati angka 1; pemberian perlakuan bisa 
meningkatkan $3-4 x$ pengetahuan dibanding dengan tidak diberikan.

\section{PEMBAHASAN}

Hasil kegiatan diatas menunjukkan bahwa kegiatan penyuluhan dapat meningkatkan pengetahuan dan keaktifan lansia tentang Posyandu Lansia dan Senam Lansia, hal tersebut dapat dilihat dengan terjadinya peningkatan nilai rata - rata peserta dari 46.18 menjadi 87.94 serta pelaksanaan senam lansia yang $\geq 75 \%$ dapat melakukan dengan benar.

$$
\text { Pendidikan kesehatan atau }
$$
penyuluhan merupakan salah satu upaya untuk mencegah terjadinya sakit atau penyakit dan meningkatkan kemauan serta kemampuan masyarakat melalui pembelajaran sehingga diharapkan masyarakat dapat menolong dirinya sendiri dan juga mau untuk berperilaku hidup sehat ataupun dapat mempertahankan perilaku sehat yang sudah dimilikinya. (Kholid, 2012)

Pengetahuan adalah hasil yang didapatkan dari mengetahui yang terjadi setelah seseorang melakukan penginderaan terhadap suatu objek tertentu. Pengetahuan seseorang dapat diperoleh dari proses belajar, dalam proses belajar sendiri terdapat faktor yang mempengaruhi seperti motivasi, sarana informasi, maupun social budaya. Pengetahuan merupakan sesuatu yang dibentuk secara terus - menerus yang akan mengalami reorganisasi oleh pemahaman - pemahaman yang baru (Budiman dan Riyanto, 2013)

Pendidikan kesehatan tentang Posyandu Lansia dan Senam Lansia bertujuan untuk memberikan informasi kepada responden tentang pengertian, manfaat, kapan, dan interpretasi. Pengertian dari pendidikan kesehatan menurut Notoatmodjo (2005) yang mendefinisikan pendidikan kesehatan merupakan suatu kegiatan atau usaha untuk menyampaikan pesan tentang kesehatan kepada individu, kelompok atau masyarakat. Penelitian Gupta, et al(2009) menjelaskan bahwa pendidikan kesehatan dapat meningkatkan pengetahuan dan praktek dalam melakukan senam lansia. Artinya pendidikan kesehatan berupaya agar individu, kelompok, atau masyarakat dapat menyadari atau mengetahui bagaimana cara untuk memelihara kesehatan, menghindari atau mencegah hal - hal yang dapat merugikan kesehatan. Hal ini dijelaskan dalam penelitian Shalini and Nayak (2011) bahwa dengan pendidikan kesehatan tentang Posyandu Lansia dan Senam Lansia dapat membantu meningkatkan kesadaran lansia untuk membina sendiri kesehatannya.

Tetapi secara umum peningkatan pengetahuan tersebut terjadi karena 
dipengaruhi oleh factor - faktor seperti informasi dari luar/media massa, pengalaman, pendidikan, usia, dan lingkungan. Informasi yang didapatkan oleh individu baik dari pendidikan formal maupun nonformal dapat memberikan pengaruh jangka pendek sehingga dapat menghasilkan adanya perubahan atau peningkatan pengetahuan (Budiman\&Riyanto, 2013).

$$
\text { Hasil dari pendampingan }
$$

pelaksanaan Senam Lansia bahwa peserta dapat melakukan dengan baik hampir $\geq$ 75\%. Perilaku seseorang akan dipengaruhi oleh pengetahuan, semakin baik pengetahuan sesorang tentang kesehatan maka orang tersebut akan melakukan pemeliharaan kesehatan dengan baik.

Hal ini sejalan dengan penelitian Aryantiningsih, Dwi Septa (2014) Menurut Green pengetahuan tidak selalu menyebabkan perubahan perilaku, namun menunjukkan hubungan yang positif antara kedua variabel tersebut. Pengetahuan dibutuhkan seseorang untuk menuntunnya dalam bertindak, sebagaimana tahapan pengetahuan yang dikemukakan Notoadmodjo, yaitu: tahu, paham, aplikasi, analisis, sintesis, dan evaluasi. Pengetahuan dapat menjadi motivasi seseorang untuk ikut melaksanakan posyandu lansia. Pengetahuan lansia yang kurang mengakibatkan kurangnya pemahaman lansia akan pentingnya posyandu lansia, sehingga menyebabkan rendahnya kunjungan lansia ke posyandu lansia. Keterbatasan pengetahuan akan mengakibatkan dampak yang kurang baik dalam pemeliharaan kesehatannya. Pengetahuan lansia akan manfatanya dapat diperoleh dari pengalaman pribadi dalam kehidupan sehari-hari. Menghadiri kegiatan posyandu lansia secara aktif, maka responden akan mendapatkan pengetahuan tentang posyandu lansia, mendapatkan penyuluhan bagaimana cara hidup sehat, dan mengetahui segala keterbatasan atau masalah kesehatan yang ada pada lansia.

\section{E. KESIMPULAN}

Ada peningkatan pengetahuan lansia tentang Posyandu Lansia dan Senam Lansia setelah diberi penyuluhan, hal tersebut terbukti dari adanya peningkatan nilai rata - rata post test lebih tinggi dari pre test.

Peningkatan keterampilan melakukan Senam Lansia, yaitu $\geq 75 \%$ dapat melakukan dengan benar.

\section{F. REFERENSI}

1. Buku Panduan Gerakan Masyarakat Hidup Sehat (GERMAS). Di kutip dari :www.dinkes.acehprov.go.id (20 November 2017).

2. Depkes. 2016. Germas Wujudkan Indonesia Sehat. Di kutip dari : www.depkes.go.id (20 November 2017).

3. Dewi, Shofia Rosma. (2015). Buku Ajar Keperawatan Gerontik. Jakarta: EGC. 
4. Kemenkes. (2017). Germas Gerakan Hidup Sehat. Jakarta: Warta Kesmas.

5. Kemkominfo. (2015). Germas. Jakarta: Biro Komunikasi Pelayanan Masyarakat dan Tim Komunikasi Pemerintah Kemkominfo.

6. Maryam, R Siti, dkk. 2011. Mengenal Usia Lanjut. Jakarta: Salemba Medika.

7. Muhith, Abdul. (2008). Pendidikan Keperawatan Gerontik. Jakarta: EGC. Dinkes Aceh. 2016.

8. Novayenni, Sabrian dan Jumaini. Pengaruh Pendidikan Kesehatan Terhadap Angka Kunjungan Lansia ke Posnyandu Lansia. JOM Ilmu Keperawatan Universitas Riau Vol 02 (01) Februari 2015: 1-8 